\title{
The FourteENTH AMENDMENT AND THE UNCONSTITUTIONALITY OF SECESSION
}

\author{
Daniel A. Farber ${ }^{*}$
}

I. Introduction

II. Antebellum Conceptions of Citizenship and the Nature of the Union

A. Secession and the Nature of the Union

B. Federalism and Citizenship in the Antebellum Period

C. Citizenship, Sovereignty, and Secession

III. Citizenship, Reconstruction, and Protection Against State Action

A. Protection and Allegiance...........................................499

B. Citizenship and Rights ..........................................501

C. Protecting the Rights of Citizens Against the States .503

D. Citizenship and the Slaughterhouse Cases

IV. Conclusion ...............................................................5 511

\section{INTRODUCTION}

April 18, 1861 was a fateful day in American history. On that day, a talented fifty-four year old army officer was offered the command of the Union Army. ${ }^{1}$ But on the same day, he learned that his home state of Virginia had decided to secede from the Union. ${ }^{2}$ Although a Southerner, he was not enthusiastic about the institution of slavery. ${ }^{3}$ He opposed secession, saying that the Framers would never have "exhausted so much labor, wisdom, and forbearance" in forming the Union "if it was intended to be broken up by every member of the [Union] at will. ${ }^{44}$ Yet, in the end, he decided that his primary allegiance was to his State,

\footnotetext{
* Sho Sato Professor of Law at the University of California, Berkeley.

1. JAMES M. MCPHERSON, BATTLE CRY OF FREEDOM: THE CIVIL WAR ERA 280-81 (1988).

2. Id. at 281 .

3. Id.

4. Id.
} 
proclaiming "I cannot raise my hand against my birthplace, my home, my children." Five days later, the officer-one Robert E. Lee-became the Commander in Chief of the Virginia military, and within a month he was a Confederate general. ${ }^{6}$ If he had accepted the offer to head the Union Army, the course of the Civil War might have been far different.

Robert E. Lee's decision exemplified the choice facing Southerners at the start of the Civil War: was their primary allegiance to their home states or to the United States of America? According to the foremost historical study of the constitutional evolution of citizenship, "the Civil War was a struggle over the nature of the community created in 1789-a bloody contest over allegiance.", Thus, "[t]he lines now were sharply drawn between those who stressed the primacy of the state communities of allegiance and those who insisted that the Union had created one nation and one people." ${ }^{8}$ After the enactment of the Fourteenth Amendment, however, the status of Americans "with respect to the states depended upon this national statute and upon their own choice or residence, and it could not be impeached or violated by state action." In short, the Civil War itself and the ensuing Fourteenth Amendment resolved the previously contested issue of the relative priority of state and national allegiance. ${ }^{10}$

A corollary flows naturally from this observation. Any remaining constitutional question about rights of states to secede was laid to rest: if allegiance to the national government was primary, action by states could not cut the bond between Americans and the national government. The text of the Fourteenth Amendment is explicit. First, anyone born or naturalized within the jurisdiction of the United States is a citizen of the

5. Id.

6. Id. at $280-81$.

7. James H. KeTtNer, THE Development OF AMERICAN CitlZeNSHIP, 1608-1870, at 340 (1978). The Development of American Citizenship remains the leading historical treatment of the subject. Douglas Bradburn, The Crtizenship Revolution: Politics and the Creation of THE AMERICAN UNION, 1774-1804 (2009), adds a valuable perspective on the development of nationalism during the early years of the Republic.

8. KeTTNER, supra note 7, at 340 .

9. Id. at 343.

10. See ERIC Foner, The Fiery Trial: Abraham LinCOLn and American SlaVery 93 (2010) ("Until after the Civil War, there existed no commonly agreed understanding of citizenship or of the rights it entailed."). Of course, this is not to say states have lost all significance to Americans. As Bruce Ackerman says:

No need to exaggerate. I don't suggest that Americans think of themselves as citizens of a unitary nation-state on the model of, say, nineteenth-century France. We remain Pennsylvanians or Oregonians as well as Americans, but the textual promise of the Fourteenth Amendment has finally become a living reality: we are Americans first. Bruce Ackerman, The Living Constitution, 120 HARV. L. REV. 1737, 1749-50 (2007). 
United States and of the state in which he or she resides. ${ }^{11}$ State citizenship is derivative and cannot be controlled by the state itself. Second, no state can deprive any American citizen of the privileges or immunities of citizenship-which means, for example, that the state cannot deprive a citizen of U.S. citizenship by seceding. ${ }^{12}$ The Privileges or Immunities Clause explicitly prohibits a state from depriving citizens of their federal rights, and secession would be a blatant violation of that prohibition.

The implications of the Citizenship Clause and the Privileges or Immunities Clause for secession should be obvious to anyone who understands how sovereignty, citizenship, and the right to national protection were interwoven in antebellum thought. But even among constitutional scholars, such knowledge is not universal, and the law review literature does not directly address this point.

The broader significance of the Fourteenth Amendment for the nature of the Union-and specifically, for the issue of secession-has been insufficiently appreciated by constitutional scholars. For instance, one leading constitutional scholar has pointed to the secession issue as a key example of the irrelevance of constitutional text:

Before the Civil War, there was a lively and inconclusive debate over whether the Constitution permitted states to secede. There is no longer

11. "All persons born or naturalized in the United States, and subject to the jurisdiction thereof, are citizens of the United States and of the State wherein they reside." U.S. CONST. amend. XIV, $\S 1$. This language derives from the Civil Rights Act of 1866, 14 Stat. 27 (1866), with a change from excepting persons "subject to any foreign power" and "Indians not taxed" with "not subject to the jurisdiction of the United States." Many supporters of the statute believed that the Thirteenth Amendment made blacks citizens when it abolished slavery. See Robert J. Kaczorowski, Revolutionary Constitutionalism in the Era of the Civil War and Reconstruction, 61 N.Y.U. L. REV. 863, 899 n.157 (1986) (citing United States v. Rhodes, 27 F. Cas. 785 (C.C.D. Ky. 1867) as exemplifying this view). For example, Senator Benjamin Wade said:

I have always believed that every person, of whatever race or color, who was born within the United States was a citizen of the United States; but by the decisions of the courts there has been a doubt thrown over that subject; and if the Government should fall into the hands of those who are opposed to the views that some of us maintain, those who have been accustomed to take a different view of it, they may construe the provision in such a way as we do not think it liable to construction at the time, unless we fortify and make it very strong and clear.

CONG. Globe, 39th CONG., IST SESS. 2768 (1866) (remarks of Sen. Wade). The Framers of the Fourteenth Amendment shared this view but wished to eliminate any remaining doubt on the question. See Richard L. Aynes, Unintended Consequences of the Fourteenth Amendment and What They Tell Us About Its Interpretation, 39 AKRON L. REV. 289, 295-97 (2006). For a review of the legislative history, see Garett Epps, The Citizenship Clause: A "Legislative History," 60 AM. U. L. REV. 331 (2010).

12. "No State shall make or enforce any law which shall abridge the privileges or immunities of citizens of the United States." U.S. CONST. amend. XIV, § 1 . 
any such debate; the issue was settled by the Civil War. No one today would seriously advance the position that the Constitution permits secession, at least the kind that the Confederacy attempted. Where is the text that settled this question? The answer, of course, is that this question, like other important constitutional questions, is decided by something other than the text. ${ }^{13}$

It is true, of course, that the Civil War resolved the issue and crystallized a new conception of the nature of the Union. It is wrong, however, to see the resolution as completely non-textual. In fact, the Fourteenth Amendment enshrines the Civil War's political transformation of the Union into Constitutional text.

In part, the victory of nationalism was embodied in the Citizenship Clause of the Fourteenth Amendment. Seth Kreimer gives a cogent explanation of this point:

At the time the United States was founded, one could conceive of American citizenship as derived from a more basic identification with each of the component states, but the time has long past when the "United States of America" was a plural construction. . . . As a political matter the Civil War resolved the issue by force of arms, and the resolution was embodied in the Citizenship Clause of the Fourteenth Amendment: persons born or naturalized in the United States are indissolubly citizens of the United States, and only derivatively or contingently citizens of the "State wherein they reside." $" 14$

Similarly, a federal judge remarked in 1871 that "[b]y the original constitution citizenship in the United States was a consequence of

13. David A. Strauss, The New Textualism in Constitutional Law, 66 GEO. WASH. L. REV. $1153,1155-56$ (1998). Strauss has made the same argument elsewhere:

In the decades leading up to the Civil War, respected political and legal figures advanced serious legal arguments, claiming descent from Jefferson's Kentucky Resolutions, in support of the right to secede. No amendment adopted after the Civil War settled this question, either expressly or by any reasonably direct implication.

Yet the question has, without doubt, been settled. The person on the street would say that the Civil War settled it, and that person would be right. The Civil War settled it, even though no formal amendment was added to the Constitution.

David A. Strauss, The Irrelevance of Constitutional Amendments, 114 HARV. L. REV. 1457, 1486 (2001) (emphasis added). Strauss is probably right that as a practical matter, the Civil War would have banished any serious claims about the right to secede even without a formal Amendment. The Fourteenth Amendment can be seen as memorializing a constitutional shift that had already taken place, at least as much as it can be considered to be the cause of the shift. But as a legal matter, the Fourteenth Amendment incorporated the newly entrenched vision of the Constitution and gave it a textual home.

14. Seth F. Kreimer, Lines in the Sand; the Importance of Borders in American Federalism, 150 U. PA. L. REV. 973, 983 (2002). 
citizenship in a state," but that under the Fourteenth Amendment "this order of things is reversed." 15 Thus, the Citizenship Clause implies that a state has no right to sever the bond between a U.S. citizen and that national government through secession or otherwise.

The Fourteenth Amendment does not, however, leave the issue of state power to implication. Although the Citizenship Clause is part of the Fourteenth Amendment's resolution of the issue of secession, the Privileges or Immunities Clause is equally important. While the Citizenship Clause makes it clear that citizens owe their primary allegiance to the federal government, the Privileges or Immunities Clause makes it clear that states have no power to interfere with the rights attaching to citizenship. Section $V$ of the Fourteenth Amendment then completes the picture, giving Congress the power to enforce the rights of citizenship against the states. In short, the Fourteenth Amendment creates a duty on citizens of allegiance toward the United States, a prohibition on state interference with those rights, and a federal power of enforcement against the states.

One reason why the Fourteenth Amendment's invalidation of secession is important is that there has been something of a revival of interest in the topic in recent years. Most notably, in April 2009, Texas Governor Rick Perry came close to threatening secession, reportedly suggesting that "Texans might at some point get so fed up they would want to secede from the union," though he said "he sees no reason why Texas should do that." ${ }^{16}$ He added:

There's a lot of different scenarios. ... We've got a great union. There's absolutely no reason to dissolve it. But if Washington continues to thumb their nose at the American people, you know, who knows what might come out of that. But Texas is a very unique place, and we're a pretty independent lot to boot. ${ }^{17}$

At the other end of the political spectrum, Thomas Naylor, a retired economics professor, published a book in 2005 advocating that Vermont withdraw from the Union. ${ }^{18}$ Academic discussion of the secession issue

15. United States v. Hall, 26 F. Cas. 79, 82 (C.C.S.D. Ala. 1871) (No. 15282).

16. Governor Says Texans May Want to Secede From Union But Probably Won't, FOXNEws.COM, Apr. 15, 2009, http://www.foxnews.com/politics/2009/04/15/governor-says-texanswant-secede-union-probably-wont/.

17. Id.

18. Thomas H. Naylor, The Vermont manifesto: The Second Vermont Republic (2005); Robert C. Black, Book Note, If at First You Don't Secede, Try, Try Again, 39 New ENG. L. REV. 839, 842 (2005) (reviewing NAYLOR, supra). See also Joseph Curl, Blue States Buzz Over 
has also increased, ${ }^{19}$ as is indicated by this Symposium itself. Although occasional uses of secessionist rhetoric should probably not be taken as serious advocacy for fragmenting the nation, they do highlight the need to clarify the nature of our constitutional order.

To understand fully the relevance of the first two clauses of the Fourteenth Amendment to secession, we need to examine the antebellum disputes about citizenship and sovereignty, the subject of Part II below. Issues about citizenship arose in the context of specific disputes about naturalization, expatriation, and the rights of freedmen, but they implicated conflicts over the seat of allegiance and the nature of the Union.

Part III turns to the Reconstruction debates and shows how they reflect a fundamentally nationalistic view of citizenship. The Reconstruction Amendments to the Constitution were connected with a powerful vision of national citizenship and its implications for federal and state power. Under this vision, the national government had the first claim to the loyalty of citizens and in return was obligated to protect their rights as American citizens against state interference. An effort by a state to secede would directly imperil the status of its residents as American citizens, and both the federal government and the residents themselves had a duty to resist this interference with their constitutional rights. The two clauses in the Fourteenth Amendment dealing most directly with citizenship embody this vision.

\section{ANTEBELLUM CONCEPTIONS OF CITIZENSHIP AND THE NATURE OF THE UNION}

It might seem obvious today that state law cannot control who is or is not a U.S. citizen. But it was not always so clear, for reasons that were related to the ultimate crisis of the constitutional order during the Civil War. Understanding the connection between citizenship and secession requires an examination of the conflicting theories of the

Secession, WASH. TIMES, Nov. 9, 2004, at Al (describing blue state buzz over secession after George W. Bush's successful re-election, some of it serious, some of it merely rhetorical).

19. See, e.g., Cynthia Nicoletti, The American Civil War as a Trial by Battle, 28 LAW \& HIST. REV. 71 (2010) (arguing that the Civil War did not resolve the legal question of the secession's constitutionality); Peter Radan, Lincoln, the Constitution and Secession, in SECESSION AS AN INTERNATIONAL PHENOMENON: FROM AMERICA'S CIVIL WAR TO CONTEMPORARY SEPARATIST MOVEMENTS 56-75 (Don H. Doyle ed., 2010) (critiquing Lincoln's arguments against secession); Michael Stokes Paulsen, The Civil War as Constitutional Interpretation, 71 U. CHI. L. REV. 691, 703-15 (2004) (endorsing Lincoln's view of secession); Akhil Reed Amar, Abraham Lincoln and the American Union, 2001 U. ILL. L. REV. 109 (2001) (critical discussion of Lincoln's view). 
Union that led to the secession crisis and their connection with antebellum conceptions of citizenship. Part A will briefly describe antebellum constitutional theories, Part B investigates conceptions of citizenship, and Part $\mathrm{C}$ ties the two topics together.

\section{A. Secession and the Nature of the Union}

Today, the Supreme Court's view of the nature of the Union holds that the Constitution transformed a loose association of states into a true national government that derived its power directly from the people. This view was expressed by the majority opinion in the Term Limits case, in which Justice Stevens' majority opinion lays out the conventional modern view of state and federal sovereignty. ${ }^{20}$ Under the Articles of Confederation, according to Justice Stevens, "the States retained most of their sovereignty, like independent nations bound together only by treaties."21 The new Constitution "reject[ed] the notion that the Nation was a collection of States, and instead creat[ed] a direct link between the National Government and the people of the United States."22 Under this view, secession by a state would have been appropriate before the ratification of the Constitution as a form of treaty revocation, but after the Constitution the states became subordinate sovereigns who had no right to interfere with the relationship between the federal government and We the People.

Before the Civil War, there were a variety of views on this issue. Abraham Lincoln was at the nationalist end of the spectrum, and his view went further than the Term Limits majority in affirming American nationhood. In Lincoln's view, the "Union is much older than the Constitution., ${ }^{23}$ Instead of viewing the Articles of Confederation as a federation between independent state sovereigns, he argued that the Union actually pre-dated the formation of the states themselves. ${ }^{24}$ From this perspective, the Constitution was simply another step in the evolution of the nation's government, merely being a revised framework to govern an already existing nation.

In effect, Lincoln's vision of nationalism made the Declaration of Independence, rather than the Constitution, the foundational national

20. U.S. Term Limits, Inc. v. Thornton, 514 U.S. 779 (1995).

21. Id. at 803 .

22. Id.

23. ABRAHAM LINCOLN, First Inaugural Address, in 4 THE COLleCted WORKS OF ABRAHAM LINCOLN 265 (Roy P. Basler ed., 1953) [hereinafter COLLECTED WORKS].

24. For a defense of Lincoln's view, see Murray Dry, Born on the Fourth of July, LEGAL AFFAIRS, Nov,/Dec. 2005, at 66. 
document. Thus, Lincoln displaced the Constitution from center stage, tying national identity much more closely to the Declaration as the initial collective statement of American nationhood. This may or may not be good history, but it surely accords with conventional Fourth of July rhetoric, which ties the Declaration not merely to the independence of individual states from Britain but more importantly to the creation of the United States.

Indeed, Lincoln insisted that that the Union was formed by the Articles of Association in 1774, even before it was "matured and continued by the Declaration of Independence in 1776."25 Because the states never had any independent existence, secession was legally impossible. As Lincoln said, "[ $t]$ he States have their status $\mathbb{I N}$ the Union, and they have no other legal status. If they break from this, they can only do so against law, and by revolution.,26

Lincoln made this constitutional vision the centerpiece of his opposition to secession. After the fall of Fort Sumter, Lincoln's message to Congress traced the Union back to 1774 and then to the Declaration of Independence: "Our States have neither more, nor less power, than that reserved to them, in the Union by the Constitution-no one of them ever having been a State out of the Union. The original ones passed in the Union even before they cast off their British colonial dependence. 27

Thus, according to Lincoln, in the Declaration of Independence,

[T]he 'United Colonies' were declared to be 'Free and Independent States'; but, even then, the object plainly was not to declare their independence of one another, or of the Union; but directly the contrary, as their mutual pledge, and their mutual action, before, at the time, and afterwards, abundantly show. ${ }^{28}$

A few years after Independence, Lincoln said, the Union was strengthened by the Articles of Confederation, which were declared to be perpetual, and then by the Constitution, which sought a "more perfect union."29 From this he deduced that secession was unconstitutional: "But if the destruction of the Union, by one, or by a part only, of the

25. LINCOLN, supra note 23 , at 265.

26. Abraham LINCOLN, Special Message to Congress, July 4, 1861, in 4 Collected WORKS, supra note 23 , at 434.

27. Id. at 433 .

28. Id.

29. LINCOLN, supra note 23 , at 265. 
States, be lawfully possible, the Union is less perfect than before the Constitution, having lost the vital element of perpetuity." ${ }^{30}$

If the Confederation was perpetual, and the Constitution created a more perfect union, then the Constitution had to provide for a perpetual bond. Moreover, because the only true sovereign government was national, Lincoln's view implied that citizenship was predominantly a national rather than state status; thus, allegiance was primarily owed to the federal government.

Lincoln's nationalist view contrasted sharply with the statecentered constitutional theory held by many Southerners. In defending the constitutionality of secession, Jefferson Davis affirmed a longstanding Southern view of the nature of the Union. During the American Revolution, Davis said, the British threat to American liberty had led to an alliance under which each state expressly retained its sovereignty. ${ }^{31}$ Davis' narrative continued with a Constitutional Convention by state-appointed delegates who negotiated what he called "a compact between independent States." S2 State sovereignty, Davis said, was then explicitly reaffirmed in the Tenth Amendment. ${ }^{33}$ But a heresy arose in the North, according to Davis-a heresy holding that that Constitution did not create a compact of states but a national government. $^{34}$

Note that Lincoln did not exactly endorse this "heresy"-instead, he viewed nationhood as pre-dating the Constitution. So, by Davis' standards, Lincoln's view was even worse than the northern "heresy;" it was practically infidel. It is little wonder that Lincoln failed to persuade Southerners of his views.

The theory advanced by Davis was hardly original. John Calhoun was perhaps the most articulate spokesman for the Southern theory of the Union. He claimed that the states had separately become sovereign when they declared independence from England. ${ }^{35}$ This sovereignty remained intact through the Articles of Confederation, and in the Constitution, all the states had done was appoint the federal government

30. Id.

31. Jefferson Davis, Message to Congress April 29, 1861 (Ratification of The Constitution), available at $\mathrm{http}: / / \mathrm{avalon}$. law.yale.edu/19th_century/csa_m042961.asp.

32. Id.

33. Id.

34. Id.

35. JoHN C. CALHOUN, A Discourse on the Constitution and Government of the United States, in Union and Liberty: THe Polttical Philosophy of John C. Calhoun 84 (Ross M. Lence ed., 1992). 
as their agent to perform certain functions. ${ }^{36}$ According to Calhoun, the "government is a federal, in contradistinction to a national government-a government formed by the States; ordained and established by the States, and for the States-without any participation or agency whatever, on the part of the people, regarded in the aggregate as forming a nation." (Notice the language "By the states ... and for the states," and contrast that language with Lincoln at Gettysburg.) There is, Calhoun said, "no such community, politically speaking, as the people of the United States, regarded in the light of, and as constituting one people or nation." 38 In short, he said, the Constitution created "the government of a community of States, and not the government of a single State or nation." 39 In a community of states, clearly the allegiance of citizens runs directly to their own state and only derivatively to the community as a whole.

Calhoun and Davis were important historical figures, but they did not evolve their theories on their own. Both drew on a larger tradition of Southern constitutionalism going back to Thomas Jefferson. Well before Calhoun, the Southern vision of the Union had begun to emerge in the Virginia and Kentucky Resolutions. ${ }^{40}$ The Kentucky Resolutions, based on a draft of Jefferson's, began with a strong affirmation of the compact theory. The states created the general government for special purposes, reserving to each state all remaining power. The Resolutions maintained that the federal government, as a creature of the compact, was not final judge of the extent of its own powers. Instead, each party to the contract had to judge for itself whether the terms of the agreement had been violated. ${ }^{41}$ The Resolutions did not speak of secession, but the logical implication was that a party to the compact could withdraw in case of a breach or repudiation of the agreement by other parties.

Thus, by the onset of the Civil War, the South already had an antinationalist, state-centered theory of the Constitution for over half a century. Indeed, according to a recent history of secession, the states'

36. Id. at $83-84$.

37. Id. at 116 .

38. Id.

39. Id. at 82 .

40. Stanley ElKins \& ERiC MCKITRICK, THE AgE of Federalism: The EARLy AMERICAN REPUBLIC, 1788-1800, at 719 (1993).

41. Kentucky Resolutions of 1798 and 1799 , in 4 THE Debates IN THE SEVERAL STATE CONVENTIONS 540, 544 (Jonathan Elliot ed., 1891). On the difference between Jefferson and Madison regarding the precise nature of the federal compact, see H. Jefferson Powell, The Principles of '98: An Essay in Historical Retrieval, 80 VA. L. REV. 689, 717-18 (1994). 
rights theory had become so familiar to Southerners by 1860 as to be boring:

Secessionists' potentially saving state's rights creed started as a legalistic bore. The 1860 secessionists (and their fathers and grandfathers) had grown up listening to endless disquisitions on how the states came before the nation, on how the states had ratified the U.S. Constitution, on how the ratifying bodies retained reserved rights and especially the right to withdraw their ratification, and how the original parties to a contract can rescind the document if its terms were violated. $^{42}$

So familiar was this theory that Southerners were outraged "when federal agents coercively violated the (white) people of a state's sovereign right to shift consent to another government. ${ }^{, 43}$ This theory became invaluable in bringing the Upper South to secede after Fort Sumter. States like Virginia had not found Lincoln's election a sufficient basis to secede, but "[i]f the federal agency coerced the people of a single state who had claimed their state's right to remove their consent and never to be enslaved, the state's rights justification could bring other southern states charging to the rescue, whatever they thought of the expediency of the first secession."

Even today, remnants of the antebellum Southern constitutional vision occasionally surface. Speaking for four members of the Court fifteen years ago, Justice Thomas invoked a similar conception of federalism. In his Term Limits dissent, he said that the "ultimate source of the Constitution's authority is the consent of the people of each individual State, not the consent of the undifferentiated people of the Nation as a whole"-adding that "the people of the several States are the only true source of power." 45 He seemed to indicate state sovereignty remains primary today: "the people of each State retained their separate political identities, ${ }^{, 46}$ and the "very name 'congress' suggests a coming together of representatives from distinct entities." ${ }^{, 47}$

Thus, although so far as we know no current Justice endorses a right to secede, elements of the antebellum Southern view linger in some present-day quarters. One implication of this article is that the

42. William W. FreEhling, RoAD to Disunion: SECESSIONISTS TRIUMPHANT, 1854-1861, at 346 (2007).

43. Id. at 349.

44. Id. at 351 .

45. U.S. Term Limits, Inc. v. Thomton, 514 U.S. 779, 846-47 (1995) (Thomas, J., dissenting).

46. Id. at 849 .

47. Id. at 857-58. 
Fourteenth Amendment completed the work of the Constitution itself in consolidating the original colonies into a true nation. Thus, the Term Limits dissenters were embracing a theory that lost whatever validity it ever had by 1867 .

\section{B. Federalism and Citizenship in the Antebellum Period}

Justice Thomas oversimplified the issue in his Term Limits dissent, but the historical record does reflect considerable uncertainty and dispute about whether the United States was truly a nation. The question of "whether the Revolution had created one community of allegiance or many" remained unresolved. ${ }^{48}$

As an important part of this larger confusion, the relationship between states and national citizenship was unclear before the Civil War. Just three weeks after the Declaration of Independence, the Continental Congress passed a resolution providing that "all persons residing within any of the United Colonies, and deriving protection from the laws of the same, owe allegiance to the said laws, and are members of such colony., ${ }^{49}$ The states quickly adopted their own naturalization laws, ${ }^{50}$ but their power over citizenship was the source of confusion.

One reason for the confusion was that citizenship in a single state had significance in other states. Each state's citizens became entitled to equal treatment in all other states under the Articles of Confederation's precursor to what is now the Privileges and Immunities Clause of Article IV. ${ }^{51}$ As Kettner says, "[a]lthough the primary locus of allegiance throughout the Confederation period was still in the individual sovereign state, the idea that citizens belonged to a larger national community surfaced frequently, never fully articulated or theoretically explored, but persuasive-almost instinctive - in certain contexts. ${ }^{, 52}$ For instance, it was unclear whether a person who had been naturalized by a state under the Articles was thereby a citizen of the United States for purposes of qualifying to sit in the United States Senate. ${ }^{53}$

Before the Civil War, the dispute over sovereignty was tied to a dispute over the meaning of citizenship. During the nullification crisis,

48. KETTNER, supra note 7, at 209.

49. Id. at 179.

50. Id. at 214-19.

51. Id. at 220.

52. Id. at 224 .

53. Id. at 234-35. For an overview of immigration policy prior to the Constitution, see James E. Pfander \& Theresa R. Wardon, Reclaiming the Immigration Constitution of the Early Republic: Prospectivity, Uniformity, and Transparency, 96 VA. L. REV. 359, 371-85 (2010). 
South Carolina insisted that the: "[A]llegiance of the citizens . . . is due to the ... State, and ... obedience only, and not allegiance, is due ... to any other power or authority, to whom a control over them has been or may be delegated by the state." ${ }^{54}$ The state legislature then passed a law requiring all militia officers to swear that they had "faithful and true allegiance" to the state. ${ }^{55}$ The law was held unconstitutional by the state appellate court, with a dissenting nullifier arguing that only the state government could command a citizen's ultimate allegiance. ${ }^{56}$

Southerners also argued that a national statute governing expatriation (abandonment of citizenship) would be unconstitutional, because it was not within any express Congressional power, leaving the matter to the states. ${ }^{57}$ As a U.S. Representative from Virginia put it, "[t]he relation to the State government was the basis of the relation to the General Government, and therefore, as long as man continues a citizen of a State, he must be considered a citizen of the United States." 58

On the eve of Civil War, the dominant Southern view was that allegiance to state government was primary. However, adherence to the primacy of state citizenship was not absolute. In the name of protecting the power of Southern states to exclude free blacks from other states, Southerners were also willing to limit the power of other states to make blacks citizens for purposes of federal law. Allowing Northern states to make blacks into citizens would have led to the unpalatable conclusion that their status as citizens in Northern states would have been entitled to recognition in Southern states under the Privileges or Immunities Clause.

Chief Justice Taney's opinion in Dred Scott contended that the Framers considered blacks "a subordinate and inferior class of beings, who had been subjugated by the dominant race, and, whether

54. KETTNER, supra note 7, at 265.

55. Id.

56. Id. at 267.

57. Id. at 282-83. Justice Paterson had taken a contrary view in the lead opinion in Talbot $v$ Jansen, 3 U.S. (3 Dall.) 133 (1795):

The act of the legislature of Virginia, does not apply. Ballard was a citizen of Virginia, and also of the United States. If the legislature of Virginia pass an act specifying the causes of expatriation, and prescribing the manner in which it is to be effected by the citizens of that state, what can be its operation on the citizens of the United States? If the act of Virginia affects Ballard's citizenship, so far as respects that state, can it touch his citizenship so far as it regards the United States? Allegiance to a particular state, is one thing; allegiance to the United States is another. Will it be said, that the renunciation of allegiance to the former implies or draws after it a renunciation of allegiance to the latter? The sovereignties are different; the allegiance is different; the right too, may be different.

Id. at 153-54. For background on the case, see BRADBURN, supra note 7, at 116-22.

58. KETTNER, supra note 7, at 283. 
emancipated or not, yet remained subject to their authority, and had no rights or privileges but such as those who held the power and the Government might choose to grant them."59 Justice Daniels managed to exceed even Taney's level of offensiveness with his dictum: "That in the establishment of the several communities now the States of this Union, and in the formation of the Federal Government, the African was not deemed politically a person." $\$ 60$ Note, however, that the Constitution refers to slaves as "persons held to servitude,"61 as Justice McLean pointed out in his dissent. ${ }^{62}$ It is also significant that citizenship had never been completely limited to whites: Indians were eligible for citizenship, and some southern courts held that free blacks automatically became state citizens. $^{63}$

James Madison himself took the view that emancipated blacks were entitled to the right of citizenship. ${ }^{64}$ Moreover, an 1803 federal statute banned ships from bringing any black into the country who were not "a native, a citizen, or registered seaman of the United States." "65 That statute clearly implies that a black could be a citizen of the United States, and in 1807, Americans had been outraged by British seizure of four "American citizens," two of whom were black. ${ }^{66}$

59. Dred Scott v. Sandford, 60 U.S. 393, 404-05 (1856). DON EDWARD FEHRENBACHER, THE DRED SCOTT CASE: ITS SIGNIFICANCE IN AMERICAN LAW AND POLITICS (1978), is a classic treatment of the historical context, legal complexities, decisional process, and impact of the case. It is more readily available in an abridged paperback, DON EDWARD FEHRENBACHER, SLAVERY, LAW, \& Politics: THE DRed SCOTT CASE IN Historical Perspective (1981). Another useful treatment is PAUL FINKELMAN, DRED SCOTT V. SANDFORD: A BRIEF HISTORY WITH DOCUMENTS (1997), which also contains excerpts from the long, meandering opinions and reprints the responses of Northern and Southern papers to the decision. For a brief introduction to the case and its effects, see RICHARD H. SEWELl, A HouSE DIVIDED: SECTIONALISM AND CIVIL WAR, 1848-1865, at 57-61 (1988).

60. Dred Scott, 60 U.S. at 481.

61. The fugitive slave clause provides:

No Person held to Service or Labour in one State, under the Laws thereof, escaping into another, shall, in Consequence of any Law or Regulation therein, be discharged from such Service or Labour, but shall be delivered up on Claim of the Party to whom such Service of Labour may be due.

U.S. CONST. art. IV, $\S 2$, cl. 3 . The point is that, while slaves may have been property, they were also persons for some constitutional purposes. Whether status as property could be squared with the right to due process created by the Fifth Amendment is a question that may have had no satisfactory resolution before the issue was rendered moot by the Civil War.

62. Dred Scott, 60 U.S. at 537 (Mclean, J., dissenting).

63. KETTNER, supra note 7, at 316-19.

64. BRADBURN, supra note 7, at 259.

65. Dred Scott, 60. U.S. at 587 (Curtis, J., dissenting).

66. BRADBURN, supra note 7, at 235-36. 
In dissent, Justice McLean pointed out that Taney's historical exegesis was remarkably one-sided: "[W]hile I admit the government was not made expecially [sic] for the colored race, yet many of them were citizens of the New England States, and exercised the rights of suffrage when the Constitution was adopted."67 In Massachusetts, for example, a proposed 1778 state constitution went down to defeat in part because it excluded blacks from the right to vote. ${ }^{68}$ This may not prove that free blacks were regarded as U.S. citizens, but it does rebut Taney's assertion that blacks were incapable of being members of the political community or of having legal rights that others were required to accept. $^{69}$

One reason for the relative paucity of evidence about the Framers' definition of citizenship is that they were rarely required to consider it. Citizenship is an important legal concept, but not necessarily decisive in a broad range of contexts. In many respects, personhood is the more important concept under the U.S. Constitution. In the Constitution itself, citizenship is mostly mentioned as a job qualification for elected federal office. $^{70}$ But there is no constitutional requirement of citizenship for appointed office as a member of the judiciary or the Cabinet; nor any limitation of the franchise to citizens.

Moreover, the Constitution allowed free blacks to participate in the selection of members of Congress, provided that the state allowed them to vote or hold office. Article I, section 2, provides that voters for House members "have the Qualifications requisite for Electors of the most numerous Branch of the State Legislature," so blacks could vote in federal elections if they could vote in state elections, regardless of

67. Dred Scott, 60 U.S. at 537.

68. BRADBURN, supra note 7 , at 245 . Bradburn believes that free blacks were close to treatment as citizens at the time of the Revolution but then were gradually demoted to the status of "denizens" in the early Nineteenth Century. Id. at 239-40.

69. The Dred Scott case continues to attract interest today, as seen by recent scholarship such as Gerald Leonard, Law and Politics Reconsidered: A New Constitutional History of Dred Scott, 34 LAW \& SOC. INQUIRY 747 (2009); Harry V. Jaffa, Dred Scott Revisited, 31 HARV. J.L. \& PUB. POL'Y 197 (2008); Jack M. Balkin \& Sanford Levinson, Thirteen Ways of Looking at Dred Scott, 82 CHI.-KENT L. REV. 49 (2007); Sarah H. Cleveland, Foreign Authority, American Exceptionalism, and the Dred Scott Case, 82 CHI.-KENT L. REV. 393 (2007); Sam Erman, An "Unintended Consequence": Dred Scott Reinterpreted, 106 MICH. L. REV. 1157 (2008).

70. See U.S. ConST. art. $1, \S 2$, cl. 2 (members of the House must have been citizens of the United States for seven years); U.S. CONST. art. I, $\$ 3, \mathrm{cl} .3$ (Senators must have been citizens of the United States for nine years and citizens of the state at the time of election); U.S. CONST. art. II, $\S 1$, cl. 5 (the President must be "a natural bom Citizen, or a Citizen of the United States, at the time of the Adoption of this Constitution"). Note that the requirements for Senators clearly distinguish between United States citizenship and citizenship in a particular state. 
whether they were citizens. ${ }^{71}$ Under Article I, section 3, members of the Senate are chosen by state legislatures, with no stated restriction on who can serve in such a legislature. ${ }^{72}$

Apart from the qualifications for political office, there were only a few provisions directly bearing on citizenship. Article I, section 8, clause 4, gives Congress the power to "establish a uniform Rule of Naturalization ... throughout the United States."73 Otherwise, citizenship shows up only in Article III's definition of diversity jurisdiction $^{74}$ and in Article IV's Privileges and Immunities Clause. ${ }^{75}$ Only in these two clauses and in the requirements for election to the Senate is state citizenship rather than federal citizenship mentioned. And notwithstanding Taney's effort to restrict Article III diversity jurisdiction to whites, there was no constitutional barrier to blacks bringing suit under Article III's admiralty or federal question jurisdiction because the Constitution does not tie these to the identity of the parties.

Citizenship seemed to have less relevance to possession of rights than mere legal personhood. Article III, section 2, clause 3 provides a right to a jury in the "Trial of all Crimes, except in Cases of Impeachment," without reference to citizenship. ${ }^{76}$ Article I, section 9 prohibits bills of attainder and ex post facto laws without any reference to the citizenship of the defendant. ${ }^{77}$ Some provisions of the Bill of Rights refer to "the people," which by Taney's reasoning might not have included blacks. ${ }^{78}$ But the Fifth and Sixth Amendments, governing due process, property confiscation, and criminal procedure, are not so limited, nor is the right to jury trial in civil cases of the Seventh Amendment.

71. U.S. CONST. art. I, $\S 2$, cl. 1.

72. U.S. CONST. art. I, $\S 3$, cl. 1.

73. U.S. CONST. art. I, $\S 8$, cl. 4.

74. Article III provides:

The judicial Power shall extend to ... Controversies . . . between a State and Citizens of another State; - between Citizens of different States; between Citizens of the same State claiming Lands under Grants of different States, and between a State, or the Citizens thereof, and foreign States, Citizens or Subject.

U.S. CONST. art. III, $\S 2$.

75. The Privileges and Immunities Clause of Article IV states that the "Citizens of each State shall be entitled to all Privileges and Immunities of Citizens in the several States." U.S. CONST. art. IV, $\$ 1$.

76. U.S. CONST, art. III, $\S 2$, cl. 3.

77. U.S. CONST. art. I, $\$ 9$, cl. 3.

78. For instance, the Fourth Amendment provides that the "right of the people to be secure in their persons, houses, papers, and effects, against unreasonable searches and seizures, shall not be violated." U.S. CONST. amend. IV. 


\section{Citizenship, Sovereignty, and Secession}

More vexing before the Civil War than the legal dimension of U.S. citizenship was its significance in terms of political obligation. Was Robert E. Lee an American citizen who owed allegiance to the United States first and foremost? If so, he was guilty of treason in taking up arms against the U.S. government and giving aid and comfort to its enemies. ${ }^{79}$ Or was he a citizen of Virginia first and foremost, in which case he was bravely defending his country (Virginia) against a foreign enemy?

These citizenship issues had an obvious link with visions of the Union. The constitutionality of secession turned on whether the United States was a confederation of states (so that being an American citizen derived from being a state citizen), or whether the United States was a genuine nation (so that American citizenship was primary). Even today, these viewpoints have left remnants in historical terminology. The former view is implicit in references to the Civil War as "the war between the states," whereas under the latter view it was a Civil War between the United States and Southern rebels.

Before the Civil War, the answer to this question was debatable, but the Constitution itself was more nationalist than many people then or now seem to realize. To begin with, there is the Preamble's intention to create "a more perfect Union" which itself was supposed to be perpetual. ${ }^{81}$ Other provisions of the Constitution, however, also speak volumes about the desire to create a powerful national government, not just an agent for a confederation of independent sovereigns. Besides granting the federal government broad powers over the economy including control of all interstate commerce,

79. U.S. CONST. art. III, $\S 3$, cl. 1 provides that "[t]reason against the United States, shall consist only in levying War against them, or in adhering to their Enemies, giving them Aid and Comfort."

80. U.S. CONST, pmbl.

81. As the Supreme Court said in Texas v. White, 74 U.S. 700 (1968):

The Union of the States never was a purely artificial and arbitrary relation. It began among the Colonies, and grew out of common origin, mutual sympathies, kindred principles, similar interests, and geographical relations. It was confirmed and strengthened by the necessities of war, and received definite form, and character, and sanction from the Articles of Confederation. By these the Union was solemnly declared to "be perpetual." And when these Articles were found to be inadequate to the exigencies of the country, the Constitution was ordained "to form a more perfect Union." It is difficult to convey the idea of indissoluble unity more clearly than by these words. What can be indissoluble if a perpetual Union, made more perfect, is not?

Id. at 724-25. In dissent, Justice Grier refused to opine on the constitutionality of secession and said that the issue had been settled through "trial by battle." Id. at 740. 
exclusive power to coin money, and the bankruptcy power, ${ }^{82}$ the Constitution invested the powers of war and peace, and the power to make treaties, in the United States. It explicitly denied those powers to the states. ${ }^{83}$ It also allowed the federal government to intervene in the internal political affairs of a state if it considers the state's form of government not to be "Republican" in nature. ${ }^{84}$

In addition, federal laws are "the Supreme Law of the Land" and override state constitutions, meaning that the people of the states gave up their plenary power to draft constitutions to suit themselves. ${ }^{85}$ The federal government also controls naturalization and hence limits the power of a state to determine who counts as a citizen. All of these provisions seem well beyond the terms of a mere confederation. The states did retain control of purely local affairs, but that role seems decidedly subordinate to the sweeping constitutional powers of the federal government to address issues of national and international importance.

To see the degree to which the Constitution created something more than a mere confederation, it may be helpful to consider a modernday analogy. Imagine a proposal to give "the United States of All the Americas (USAA)" the power to replace the U.S. dollar with a new currency, while disbanding the U.S. Army in favor of a military controlled by a president elected by North and South Americans. The USAA also controls all international trade in the Americas and takes over control of immigration issues. On top of this, the laws of the USAA override the U.S. Constitution. It is hard to imagine that anyone would think this organization was just a federation of existing states like NATO or that the USAA was merely acting as an agent for individual governments like the IMF or World Bank today.

Even more than the extensive national powers given to the U.S. government, the title of the document speaks strongly of nationhood. Its predecessor was called the Articles of Confederation. Eschewing this term, the new title is "Constitution of the United States." According to the Preamble, this national constitution is "ordain[ed] and establish[ed] . . . for the United States of America" by "We the People of the United

82. U.S. ConST. art. I, $\S 8, \mathrm{cl} .3$ (commerce power); cl. 4 (bankruptcy); cl. 5 (control of the money supply). Other economic powers include control of intellectual property rights, art. $1, \S 8$, cl. 8; the taxing and spending powers, cl. 1; and control of weights and measures, cl. 5.

83. U.S. CONST. art. I, $\S 10, \mathrm{cl} .1,3$.

84. U.S. CONST. art. IV, $\S 4$.

85. U.S. CONST. art. VI, $\S 2$. 
States" in order "to form a more perfect Union." very much like the creation of a nation-as the union of Scotland and England created the United Kingdom. ${ }^{87}$

Notably, the Constitutional Convention sent the Continental Congress a letter explaining its efforts. ${ }^{88}$ The letter spoke of the need to place key powers "fully and effectually" in the federal government, which admittedly would require some sacrifice of state sovereignty. ${ }^{89}$ Moreover, the letter says: "In all our deliberations on this subject we kept steadily in our view, that which appears to us the greatest interest of every true American, the consolidation of our Union, in which is involved our prosperity, felicity, safety, perhaps our national existence."90 The references to "consolidation" and to "our national existence" are inconsistent with the notion of a confederation. The letter closes with the hope that the Constitution "may promote the lasting welfare of that country so dear to us all, and secure her freedom and happiness"-rather than the "welfare of the countries dear to each of us." 91 This is nationalist language, not the language of a compact between independent sovereigns.

Still, the case of American nationhood (and with it, the case against secession) cannot be considered ironclad before the Civil War. As Madison pointed out in Federalist 39, the structure of the government contained ambiguities. $^{92}$ Madison pointed to nationalist features of the Constitution such as the operation and extent of federal powers. ${ }^{93}$ Yet the governance structure relied heavily on the states as separate entities (such as the election of Senators by state legislatures), and the ratification process was by state conventions rather than a national vote.

86. U.S. CONST. pmbl.

87. On the resemblance between the formation of the U.K. and the Constitution, see Akhil Reed Amar, Architexture, 77 IND. L.J. 671, 683 (2002) ('The phrase 'perfect Union' in fact echoes language from the Union of England and Scotland in 1707, as Publius reminds his readers in The Federalist No. 5").

88. The text of the letter can be found in Daniel A. Farber, The Constitution's Forgotten Cover Letter: An Essay on the New Federalism and the Original Understanding, 94 MicH. L. REV. $615,649-50$ (1995).

89. Id. at 649 .

90. Id.

91. Id. at 650 .

92. The FEDERALIST No. 39, at 239 (James Madison) (Henry Cabot Lodge ed., 1888).

93. Id. 


\section{CITIZENShIP, ReCONSTRUCTION, AND PRoteCtion AgAINST STATE} ACTION

In short, although the Constitution bears strong marks of nation building, there was no smoking-gun proof of the nature of the Union in the constitutional text that could decisively prevent Southerners from adopting a states-rights vision. As Part III will explain, that smoking gun was supplied by the Fourteenth Amendment. What was arguably still an open question in 1860 was answered in no uncertain terms in 1866 with the adoption of the Fourteenth Amendment.

The relevant portions of the Fourteenth Amendment are familiar but their significance is obscure today because we have lost the historical context that made issues of U.S. citizenship so foundational to the constitutional regime. The first sentence of the amendment provides that "All persons born or naturalized in the United States, and subject to the jurisdiction thereof, are citizens of the United States and of the State wherein they reside." ${ }^{.94}$ Only with the passage of this amendment did it become incontestable that state citizenship was merely a geographic byproduct of federal citizenship. Correspondingly, the second sentence of the amendment prohibits states from interfering with the privileges and immunities of national citizenship. ${ }^{95}$ The upshot of these sections is the United States involves a direct relationship between the federal government and citizens that is beyond any form of interference by the states, which enjoy only a secondary right to allegiance from their residents. While the two clauses may seem to deal only with some narrowly-defined legal issues relating to citizenship, the implications were much broader.

Part III discusses the implications of this change for the issue of secession. The right to secede is a natural feature of a confederation where citizens owe allegiance to their own individual local governments, but out of place in a nation that demands the primary allegiance of its citizens and in turn promises to protect their rights from interference by local governments.

We will begin in Part A by examining the reciprocal relationship between a citizen's allegiance to the sovereign and the right to protection by the sovereign. Part B shows how these ideas entered the Reconstruction view of the Article IV Privileges and Immunities Clause. Then, Part $\mathrm{C}$ shows how concepts of allegiance and protection were put to use in the Reconstruction debates to support the right of American

94. U.S. CONST. amend. XIV, \& 1.

95. Id. 
citizens to national protection against infringement by their own state governments. Finally, Part D shows how the Supreme Court viewed the relationship between citizenship and rights after the Civil War. Although the Court took a narrow view of what rights inhered in national citizenship, it clearly understood that national citizenship was primary and beyond the reach of state authority.

\section{A. Protection and Allegiance}

According to legal historian Philip Hamburger, "[t]he reciprocal relation of allegiance and protection . . . became a foundation of American government." 96 As we will see, this concept was deeply embedded in the common law and in the thinking of the Republicans who passed the Fourteenth Amendment. It implied that, if residents of seceding states remained U.S. citizens, they were entitled to the protection of the U.S. government against would-be secessionists and to enforcement of their rights under federal law.

The connections between citizenship, allegiance, and government protection went back in English law at least to the time of Lord Coke, who was faced with such issues in the context of determining the rights of citizens of Scotland under English law during the reign of James I. ${ }^{97}$ James had become King of both England and Scotland, but the countries had separate parliaments, so it was not clear how their citizenships related. ${ }^{98}$ Fundamental to Coke's analysis was the proposition that the "bond between the subject and the sovereign . . . involved reciprocal obligations" of allegiance and protection that attached at birth. ${ }^{99}$ The duty of allegiance to the King and the correlative rights to "the King's legal protection" were explicit in the case. ${ }^{100}$ Because Scots born after the Union received the protection of James, who was monarch of both Scotland and England, they acquired a duty of allegiance to both states and hence citizenship in both parts of the realm.

In the American Civil War, both sides claimed entitlement to allegiance, in each case implying that violations of allegiance would constitute treason. Based on the theory that individual allegiance flowed

96. Philip Hamburger, Beyond Protection, 109 COLUM. L. REV. 1823, 1853 (2009).

97. KETTNER, supra note 7, at 16-17.

98. Id. at 16.

99. Id. at 18 .

100. See Polly J. Price, Natural Law and Birthright Citizenship in Calvin's Case (1608), 9 YALE J.L. \& HuMAN. 73, 88-89 (1997). Francis Bacon's argument for the plaintiff insisted that allegiance was due under the law of nature. Id. at 109-10. Coke accepted this theory. Id. at 113, 115. 
fundamentally to the states, the Confederacy maintained that no change in allegiance took place at secession. Thus, unlike the American Revolution, where individuals were considered to have a period in which to choose allegiance, the allegiance of Southerners automatically remained with the existing states when those state governments chose to sever their relationship with the federal government. ${ }^{101}$ Hence, after secession, Southern Unionists were subject to the law of treason. A similar situation would arise today if the United States decided to leave the United Nations or NATO. Such a decision would clearly have no effect on the status of U.S. citizens who would remain citizens of the United States, not citizens of NATO, and Americans who chose to side with NATO against the United States in a military conflict would be guilty of treason. For the same reason, according to Confederate legal theory, Southerners who decided to side with the North after secession were guilty of treason. ${ }^{102}$

As might be expected, Northerners took a different view. The significance attached to national citizenship and allegiance in the North became evident in the early days of the war. In the Prize Cases,${ }^{103}$ for example, the Supreme Court was required to determine not only the president's power to impose a blockade, but also the relationship of Southerners to the federal government after the outbreak of the war. ${ }^{104}$ The Court strongly affirmed presidential power to react to the emergency without waiting for congressional approval or a declaration of war. When war broke out, the Court said, "[t]he President was bound to meet it in the shape it presented itself, without waiting for Congress to baptize it with a name; and no name given to it by him or them could change the fact." 105 As to the question of the status of the citizens in the South, the Court said, "[t]hey have cast off their allegiance and made war on their Government, and are none the less enemies because they

101. KETTNER, supra note 7 , at 335 .

102. Id.

103. 67 U.S. (2 Black) 635 (1862).

104. Id. at $640-41$. In attempting to uphold the blockade, the federal government was put in a difficult position. On the one hand, it was committed to the position that secession was legally void and that Southerners remained citizens of the United States subject to American municipal law. The implication of this view was that the Civil War was in effect a police action against a band of criminals. But such a police action would not give the United States the right under the law of nations to impose a blockade on neutrals on the high seas, nor would it give the Government the right under the Constitution to seize the property of citizens who were not proved to be members of the criminal group. Those remedies were available only against enemy aliens. Republicans uneasily straddled these conflicting theories.

105. Id. at 669 . 
are traitors." "In an affirmation of nationalism, the Court also said that citizens owe "supreme allegiance" to the federal government but only "qualified allegiance" to their states. ${ }^{107}$ Note that this holding anticipates the view ultimately enshrined in the Citizenship Clause of the Fourteenth Amendment.

\section{B. Citizenship and Rights}

Given the emotional significance of allegiance during the sectional conflict and the expansion of national power under the stress of war, it is not remarkable that Republicans used the concept of national citizenship to justify their support for the Civil Rights bill. Republicans invoked the Privileges and Immunities Clause in Article IV, Section 2, of the original Constitution. As we will see, they believed that the clause had already established the connection between United States citizenship and fundamental rights.

Congressional Republicans had their own theory of citizenship, based in part on the Privileges and Immunities Clause of Article IV. Section 2 of Article IV provides that "[t]he citizens of each State shall be entitled to all Privileges and Immunities of Citizens in the several States." 108 This language is somewhat unclear. One reading is that "in the several states" tells us both where the rights are protected and which rights exist (those created severally-that is separately-in particular states). On this reading, the clause prohibits states from discriminating against citizens of other states. But the other reading is that the "privileges and immunities of citizens" are national in scope rather than being defined by particular state. Every law student today learns the antidiscrimination meaning of the clause, which may well be the correct interpretation. But Republicans, as we will see, often favored the national rights interpretation.

The Republican interpretation of this clause relied heavily on Corfield v. Coryell. ${ }^{109}$ In Corfield, Justice Bushrod Washington said that

106. Id. at 674 .

107. "Under the very peculiar Constitution of this Government, although the citizens owe supreme allegiance to the Federal Government, they owe also a qualified allegiance to the State in which they are domiciled." Id. at 673.

108. U.S. CONST. art. IV, \$2 2.

109. Corfield v. Coryell, 6 F. Cas. 546 (C.C.E.D. Pa. 1823) (No. 3,230). See also Douglas v. Stephens, 1 Del. Ch. $465,469-74,476-77$ (1821). Corfield has some resemblance to the Supreme Court's current view of the Comity Clause, which also uses a fundamental rights analysis, although the modern Court uses the idea of fundamental rights as a limitation on the anti-discrimination prohibition rather than viewing it as the core of the clause's meaning. For a critique of Corfield and 
the Comity Clause protected "those privileges and immunities which are, in their nature, fundamental; which belong, of right, to the citizens of all free governments; and which have, at all times, been enjoyed by the citizens of the several states." 110 Among these rights were "[p]rotection by the government; the enjoyment of life and liberty, with the right to acquire and possess property of every kind, and to pursue and obtain happiness and safety; subject nevertheless to such restraints as the government may justly prescribe for the general good of the whole." 11

This interpretation of the Privileges and Immunities Clause figured prominently in the debates on the 1866 Civil Rights bill. One purpose of the Fourteenth Amendment was to constitutionalize the Civil Rights Act, so the debates on that statute are particularly relevant to understanding the amendment.

In the Senate debate on the 1866 act, Senator Lyman Trumbull referred to the Privileges and Immunities Clause to support the constitutionality of federal civil rights legislation at a time when the Fourteenth Amendment did not yet exist. He argued that:

The rights of a citizen of the United States were certain great fundamental rights, such as the right to life, to liberty, and to avail one's self of all the laws passed for the benefit of the citizen to enable him to enforce his rights; inasmuch as this was the definition given to the term as applied in that part of the Constitution, I reasoned from that, that when the Constitution had been amended and slavery abolished, and we were about to pass a law declaring every person, no matter of what color, born in the United States a citizen of the United States, the same rights would then appertain to all persons who were clothed with American citizenship. ${ }^{112}$

In the House, Representative Henry Wilson argued that the rights protected in the bill were not new because they were already contained in the Comity Clause as construed in Corfield. In his view, that clause represented a "general citizenship" which "entitles every citizen to

its use as a limitation on the clause, see Stewart Jay, Origins of the Privileges and Immunities of State Citizenship under Article IV, available at http://ssm.com/abstract=185377.

110. Corfield, 6 F. Cas. at 551-52.

111. Id. For a more in-depth discussion of the case, see David R. Upham, Note, Corfield v. Coryell and the Privileges and Immunities of American Citizenship, 83 TEX. L. REV. 1483 (2005).

112. CONG. GLOBE, 39TH CONG., 1ST SESS. 600 (1866). See also id. at 476 (bill protects "fundamental rights belonging to every man as a free man"). Trumbull used somewhat similar language in connection with the Freedmen's Bureau bill. See id. at 319, 322. 
security and protection of personal rights." $113 \mathrm{He}$ argued that the bill protected rights belonging to "citizens of the United States, as such."114

Representative Lawrence discussed the role of the Comity Clause in great detail in his response to the President's veto of the bill. He stated:

I maintain that Congress may by law secure the citizens of the nation in the enjoyment of their inherent right of life, liberty, and property, and the means essential to that end, ... . to enforce the observance of the provisions of [the Comity Clause], and the equal civil rights which it recognizes or by implication affirms to exist among citizens of the same State. ${ }^{115}$

Lawrence concluded, after a discussion of some of the cases and writings dealing with the Comity Clause, that it embodies "equal fundamental civil rights for all citizens." 116

Thus, even before the Fourteenth Amendment, members of the Reconstruction saw Congress as having the power to protect the rights of citizens from violation by state government. They rooted this understanding in a clause protecting the "privileges and immunities of citizens in the several states." When it came time to ensure that their constitutional views were entrenched in the constitutional text, they chose similar but more explicit language relating to the "privileges or immunities of citizens of the United States."

\section{Protecting the Rights of Citizens Against the States}

Another concept played an important role in the debates over the Civil Rights Act: the idea that citizens owe allegiance to their government in exchange for the government's grant of protection to them. Thus, one of the most important rights of citizenship is the right to receive such protection. This concept served not only as a possible source of rights, but also as a source of power to protect the rights of citizens that might arise from other sources such as the Privileges and Immunities Clause.

113. Id. at 1118 .

114. Id. at 1294.

115. Id. at 1835 .

116. Id. at 1836. See also id. at 1263 (remarks by Rep. Broomall listing free speech as one of the "rights and immunities of citizens"); id. at 1266 (remarks of Rep. Raymond listing "right to bear arms" as a right of citizens); id. at 1293-94 (remarks of Rep. Shellabarger, right of petition is an "indispensable" right of citizenship). 
Early in the debates on the Civil Rights Act, Senator Reverdy Johnson raised the argument that the federal government had a duty to protect its citizens from state interference with their rights:

If I am right . . . that we can authorize them [blacks] to sue, authorize them to contract, authorize them to do everything short of voting, it is not because there is anything in the Constitution of the United States that confers the authority to give to a negro the right to contract, but it is because it is a necessary, incidental function of a Government that it should have authority to provide that the rights of everybody within its limits shall be protected, and protected alike. ${ }^{117}$

Senator Johnson concluded that it "would have been a disgrace to the members of the [Constitutional] Convention" if they had foreseen the abolition of slavery and "had denied to the Congress of the United States the authority to pass laws for the protection of all the rights incident to the condition of a free man." 118 His argument was echoed by Senator Morrill. ${ }^{119}$

A similar argument was made in the House by Representative Broomall. He made a sweeping, non-textual argument:

But throwing aside the letter of the Constitution, there are characteristics of Governments that belong to them as such, without which they would cease to be Governments. The rights and duties of allegiance and protection are corresponding rights and duties. . . . [Wherever] I owe allegiance to my country, there it owes me protection, and wherever my Government owes me no protection I owe it no allegiance and can commit no treason. ${ }^{120}$

Broomall attacked the idea that such protection could be left to the states, inasmuch as "everybody knows that the rights and immunities of citizens were habitually and systematically denied in certain States to the citizens of other States: the right of speech, the right of transit, the right of domicil [sic], the right to sue, the writ of habeas corpus, and the right of petition." ${ }^{, 121}$ Broomall also argued that the necessity for the bill was not limited to blacks because loyal whites were being denied their basic rights in the South. ${ }^{122}$

117. Id. at 530. See also Johnson's expostulation in response to a contrary argument by Sen. Henderson. Id. at 572 .

118. Id. at 530.

119. Id. at 570 (remarks of Sen. Morrill).

120. Id. at 1263 .

121. Id.

122. Id. 
Representative Wilson made one of the most forceful arguments based on the duty to protect. He argued that the bill did not establish new rights, but instead protected and enforced those which already belonged to every citizen. In his opinion, the Comity Clause entitled every citizen to protection of personal rights. He summarized his defense of congressional power as follows:

If a citizen of the United States should go abroad, and while within the jurisdiction of a foreign Power be despoiled of his rights of personal security, personal liberty, or personal property contrary to the due course of law of the nation inflicting the wrong, this Government would espouse his cause and enforce redress even to the extremity of war. ${ }^{123}$

From the power to protect U.S. citizens from foreign powers by war, Wilson deduced as a lesser-included case the power to protect citizens from their own state governments by peaceful means:

[I]f all the terrible powers of war may be resorted to for the protection of the rights of our citizens when those rights are disregarded and trampled on beyond our jurisdiction, is it possible that our Constitution is so defective that we have no power under it to protect our citizens within our own jurisdiction through the peaceful means of statutes and courts? $?^{124}$

Thus, Wilson concluded, the federal government had the inherent power to prevent states from violating the rights of U.S. citizens:

I assert that we possess the power to do those things which Governments are organized to do; that we may protect a citizen of the United States against a violation of his rights by the law of a single State; . . that this power permeates our whole system, is a part of it, without which the States can run riot over every fundamental right belonging to citizens of the United States; that the right to exercise this power depends upon no express delegation, but runs with the rights it is designed to protect. ${ }^{125}$

Likewise, Representative Shellabarger stressed that because citizens owe their primary allegiance to the federal government, the government's primary duty correspondingly was to protect them. Like Wilson, Shellabarger argued that if the states could abridge those rights which the United States is bound to protect, even by a declaration of war

123. Id. at 1119 . Wilson reiterated essentially the same argument. Id. at App. 157, 1294.

124. Id. at 1119 .

125. Id. A similar view was articulated by Representative Shellabarger. Id. at 1293. 
in the case of violations by foreign governments, then "the United States is no nation." 126

After President Andrew Johnson's veto of the Civil Rights Bill, Senator Trumbull made an important speech in the Senate defending the bill against Johnson's charges. He asserted:

To be a citizen of the United States carries with it some rights; . . . They are those inherent, fundamental rights which belong to free citizens or free men in all countries, such as the rights enumerated in this bill, and they belong to them in all the States of the Union. ${ }^{127}$

In short, he said, "the right of American citizenship means something." 28 That is a truism today, but would have been contested by Southerners before the war, who viewed American citizenship as nothing but a proxy for citizenship in Virginia or some other state.

Trumbull stated that citizens are entitled to protection within the states as well as abroad. He asserted that "American citizenship would be little worth" if it did not carry protection with it:

How is it that every person born in these United States owes allegiance to the Government? Everything that he is or has, his property and his life, may be taken by the Government of the United States in its defense ... and can it be that ... we have got a Government which is all-powerful to command the obedience of the citizen, but has no power to afford him protection? Is that all that this boasted American citizenship amounts to? . . Sir, it cannot be. ${ }^{129}$

Trumbull staunchly rejected this limited view of the nature of citizenship:

Such is not the meaning of our Constitution. Such is not the meaning of American citizenship. This Government, which would go to war to protect its meanest-I will not say citizen-inhabitant ... in any foreign land whose rights were unjustly encroached upon, has certainly some power to protect its own citizens in their own country. Allegiance and protection are reciprocal rights. ${ }^{130}$

The right to protection was embodied in the Fourteenth Amendment, which prohibited states from interfering with the rights of citizens or any inhabitant to due process and equal protection. Yet

126. Id.

127. Id. at 1757 .

128. Id.

129. Id.

130. $I d$ 
secession truncates the rights of national citizenship for any citizens who remain in the state. Under the Fourteenth Amendment, states do not have the power to impair these rights of national citizenship, and section 5 of the Amendment explicitly gives Congress the power to take any necessary action to deal with the situation. ${ }^{131}$

\section{Citizenship and the Slaughterhouse Cases}

When it came time for the Supreme Court to interpret the Reconstruction Amendments, the significance of national citizenship was not overlooked. The appellants in the Slaughterhouse Cases argued that:

The doctrine of the "States-Rights party," led in modern times by Mr. Calhoun, was, that there was no citizenship in the whole United States, except sub modo and by the permission of the States. According to their theory the United States had no integral existence except as an incomplete combination among several integers. The fourteenth amendment struck at, and forever destroyed, all such doctrines. .. By it the national principle has received an indefinite enlargement. The tie between the United States and every citizen in every part of its own jurisdiction has been made intimate and familiar. ${ }^{132}$

This argument reflected a clear understanding of how the Fourteenth Amendment solidified the bond between citizens and the national government.

Similarly, in his dissent, Justice Stephen Field also clearly articulated the import of the amendment for national citizenship and its accompanying rights. He began by demonstrating his awareness of the past confusion on this topic:

The first clause of this amendment determines who are citizens of the United States, and how their citizenship is created. Before its enactment there was much diversity of opinion among jurists and statesmen whether there was any such citizenship independent of that of the State, and, if any existed, as to the manner in which it originated. With a great number the opinion prevailed that there was no such citizenship independent of the citizenship of the State. Such was the opinion of Mr. Calhoun and the class represented by him. ${ }^{133}$

131. Section 5 provides that " $[\mathrm{t}]$ he Congress shall have power to enforce, by appropriate legislation, the provisions of this article." U.S. CONST. amend. XIV, $\S 5$.

132. The Slaughter-House Cases, 83 U.S. 36, 52-53 (1872).

133. Id. at 94 . 
After recounting the holding in Dred Scott, Field explained how the Fourteenth Amendment settled the question of who possessed citizenship as well as of the significance of citizenship as a source of rights:

The first clause of the fourteenth amendment changes this whole subject, and removes it from the region of discussion and doubt.... A citizen of a State is now only a citizen of the United States residing in that State. The fundamental rights, privileges, and immunities which belong to him as a free man and a free citizen, now belong to him as a citizen of the United States, and are not dependent upon his citizenship of any State. ${ }^{134}$

Of course, the views of the advocates and the dissent are less significant than the view of the majority. While the majority opinion rejects the sweeping vision of national rights advocated by Fields and respondent's attorneys, it reflects a clear understanding of the primacy of national citizenship and of the fact that this citizenship carries with it genuine rights. ${ }^{135}$

Like the dissent, the majority opinion displays an awareness of the pre-War confusion regarding citizenship. Justice Samuel Miller recounted the antebellum disputes about citizenship. First, he said, there was confusion over the status of individuals born within the United States but not in any state:

It had been said by eminent judges that no man was a citizen of the United States, except as he was a citizen of one of the States composing the Union. Those, therefore, who had been born and resided always in the District of Columbia or in the Territories, though

134. Id. at 95 .

135. Texas $v$. White, 74 U.S. 700 (1868), also tangentially touches upon citizenship. In the first half of the decision, the Court held that Texas never seceded from the United States: "The Constitution, in all its provisions, looks to an indestructible Union, composed of indestructible States." Id. at 725 . In considering whether the actions of Texas rebel legislature were valid, the Court held that citizens' individual obligations to the Constitution were pre-eminent over their obligations to their state:

Obligations often remain unimpaired, while relations are greatly changed. The obligations of allegiance to the State, and of obedience to her laws, subject to the Constitution of the United States, are binding upon all citizens, whether faithful or unfaithful to them; but the relations which subsist while these obligations are performed, are essentially different from those which arise when they are disregarded and set at nought. And the same must necessarily be true of the obligations and relations of States and citizens to the Union. . . . The government and the citizens of the State, refusing to recognize their constitution obligations, assumed the character of enemies, and incurred the consequences of rebellion.

Id. at 727 . 
within the United States, were not citizens. Whether this proposition was sound or not had never been judicially decided. ${ }^{136}$

More significant, however, was the issue of black citizenship. Dred Scott was not forgotten:

But it had been held by this court, in the celebrated Dred Scott case, only a few years before the outbreak of the civil war, that a man of African descent, whether a slave or not, was not and could not be a citizen of a State or of the United States. This decision . . . had never been overruled; and if it was to be accepted as a constitutional limitation of the right of citizenship, then all the negro race who had recently been made freemen, were still, not only not citizens, but were incapable of becoming so by anything short of an amendment to the Constitution. ${ }^{137}$

Justice Miller explained how the Citizenship Clause resolved these issues:

The first observation we have to make on this clause is, that it puts at rest both the questions which we stated to have been the subject of differences of opinion. It declares that persons may be citizens of the United States without regard to their citizenship of a particular State, and it overturns the Dred Scott decision by making all persons born within the United States and subject to its jurisdiction citizens of the United States. $^{138}$

Miller then listed some privileges and immunities of national citizenship that are protected against state interference. The rights on his list are, at least today, quite uncontroversial, but we should keep in mind that a state's secession would have deprived each of its citizens of every right on the list except to the extent that some later treaty might allow foreigners from the seceded state to exercise these rights. Justice Miller's list included the following:

- "[T]he right of the citizen of this great country, protected by implied guarantees of its Constitution, 'to come to the seat of government to assert any claim he may have upon that government, to transact any business he may have with it, to seek its protection, to share its offices, to engage in administering its functions. He has the right of free access to its seaports, through which all operations of foreign

136. The Slaughter-House Cases, 83 U.S. at 72-73.

137. Id. at 73 .

138. Id. 
commerce are conducted, to the subtreasuries, land offices, and courts of justice in the several States." $" 139$

- "Another privilege of a citizen of the United States is to demand the care and protection of the Federal government over his life, liberty, and property when on the high seas or within the jurisdiction of a foreign government." ${ }^{\text {140 }}$

- "The right to peaceably assemble and petition for redress of grievances, the privilege of the writ of habeas corpus, are rights of the citizen guaranteed by the Federal Constitution."141

- "The right to use the navigable waters of the United States, however they may penetrate the territory of the several States, all rights secured to our citizens by treaties with foreign nations, are dependent upon citizenship of the United States, and not citizenship of a State."142

- "[A] citizen of the United States can, of his own volition, become a citizen of any State of the Union by a bona fide residence therein, with the same rights as other citizens of that State. ${ }^{143}$

- "To these may be added the rights secured by the thirteenth and fifteenth articles of amendment, and by the other clauses of the fourteenth." 144

Most of these rights relate to American nationhood-the citizen's connection with the federal government and the right to recognition of national citizenship by every state. Secession would obviously interfere with these rights-for instance, no longer would citizens of another state retain the right to enter and become citizens of the seceded state or to use the navigable waters in that state, nor would the citizens of the seceded state retain their rights as American citizens. The Privileges or Immunities Clause of the Fourteenth Amendment makes it clear that no state has the power to deprive U.S. citizens within its borders of these rights.

139. Id. at 79 .

140. Id.

141. Id.

142. Id. at 79-80.

143. Id. at 80 .

144. Id. 


\section{CONCLUSION}

School children today pledge allegiance "to the flag of the United States of America, and to the republic for which it stands, one nation, under God, indivisible, with liberty and justice for all." Much of constitutional import is captured by this pledge: that allegiance is to the United States as "one nation," not a confederation; that the nation is "indivisible," not subject to being divided by secession; and that all of this is tied with a national guarantee of "justice for all," which is to say protection of the rights of individuals.

Before the Civil War and the Fourteenth Amendment, none of this could have been said with complete assurance. Southerners, and a significant number of Northerners, would have thought it more correct for the pledge to refer to the flag and "to the republics for which it stands, one Confederation, divisible at the will of any state, with liberty and justice for all white men."

This hypothetical pledge would have encapsulated the Southern constitutional vision for the benefit of school children. Prior to the Civil War, the state governments were primarily responsible for meeting the basic needs of American citizens. The national government had little impact on the daily lives of most Americans. Consequently, before the war, state citizenship was usually paramount in practical importance, and arguably of paramount legal importance as well. From this premise, it was a small step to the conclusion that allegiance to the state came before allegiance to the federal government, as Southerners like Robert E. Lee reluctantly decided. But such concepts obviously could not survive the Civil War, a war fought in large part over the primary allegiance of the citizen. The decision to defeat secession by force necessarily implied that the citizen's relationship to the national government took precedence over his or her relationship to the state.

How far we have come from the antebellum Southern view of the Union was illustrated recently during former Governor Sarah Palin's bus tour. Although Palin is no friend of federal power, ${ }^{145}$ her bus touts the indivisibility of the American Republic: "You'll never guess the colors of the Palin bus. In huge letters it has the closing Pledge of Allegiance line: 'One nation, under God, indivisible with liberty and justice for all.' Plus an image of the Declaration of Independence with the words 'We

145. See, e.g., Robert Faturechi, Palin takes jabs, makes no promises, L.A. TIMES, May 2, 2011, at AA2 (Palin delivers "searing critique of big government"). 
the people.",146 "Indivisible," of course, means that the nation cannot be divided through secession.

Given the Fourteenth Amendment, it is clear that today's pledge is correct: we owe our primary allegiance to the United States, which is a nation rather than a confederation, and which in return offers us protection for our rights as citizens. Correspondingly, states, as building blocks of the nation, have only second place in our allegiance with state citizenship being defined by the Fourteenth Amendment as only a geographic marker depending on where an American citizen happens to reside at any given time.

Today, then, there would be no doubt about the choice facing a modern-day Robert E. Lee. He could live up to his obligations as a citizen of the "indivisible" United States. Or, by joining an unconstitutional armed rebellion, he could attempt to assist a state in destroying the privileges and immunities of national citizenship for its own residents. In using force on behalf of this effort, he would have to make war against the United States and give aid and comfort to the enemy. For him to claim that his primary allegiance was to his home state rather than the national government would be to profoundly mistake the nature of the post-Civil War constitutional order. In Lee's time, perhaps there was some basis for good faith confusion on this point, but after the Civil War and the Fourteenth Amendment, there can be no question about the unconstitutionality of secession.

146. Andrew Malcolm, Sarah Palin and her 'One Nation' bus tour, coming to a town near voters soon, L.A. TIMES, May 26, 2011, http://latimesblogs.latimes.com/washington/2011/05/sarahpalin-bus-tour-memorial-day-.html. 